\title{
STAROSNE GRANICE KRIVIČNO-PRAVNOG MALOLJETSTVA U UPOREDNOM PRAVU
}

Izv. prof. dr. Vedad Gurda*

\author{
UDK 347.157 \\ https://doi.org/10.30925/zpfsr.41.3.6 \\ Ur.: 4. srpnja 2020. \\ Pr.: 3. rujna 2020. \\ Pregledni rad
}

\begin{abstract}
Sažetak
U radu je dat uporedno-pravni prikaz starosnih granica krivično-pravnog maloljetstva, kao dobnog okvira u kojem mlade osobe, zbog svoje nedoraslosti, uživaju posebni (povlašteni) krivično-pravni status. Kada je riječ o donjoj granici, kao granici nastupanja krivično-pravnog maloljetstva i odgovornosti, ona se kreće od šest ili sedam godina u pojedinim državama, pa sve do osamnaest godina. U većini evropskih država ova granica se veže za uzrast od 14 godina, što predstavlja minimalnu dob sposobnosti za kršenje krivičnog zakona koju predlaže Komitet UN za prava djeteta. U uporednom pravu značaj ove starosne granice je u pojedinim zakonodavstvima relativiziran propisivanjem dviju ili više takvih granica (u zavisnosti od težine krivičnih djela ili zbog primjene doli capax doktrine), kao i primjenom još nekih rješenja. S druge strane, u većini država krivično-pravno maloljetstvo traje do navršenih osamnaest godina, premda u pojedinim državama u SAD-u i nekim drugim vanevropskim državama ono prestaje $i$ ranije. Značaj ove granice u pojedinim zakonodavstvima je relativiziran mogućnošću primjene maloljetničkog krivičnog prava i na (mlađe) punoljetne osobe, ali i mogućnošću upućivanja (transfera) maloljetnika na postupanje krivičnih sudova opće nadležnosti (,sudova za odrasle“) i prije prestanka maloljetstva. U radu su analizirani međunarodni standardi koji se odnose na ova pitanja, kao i legislativna rješenja u državama iz regiona. Zaključno je konstatirano kako su rješenja koja sadrže maloljetnička krivična zakonodavstva država s prostora bivše SFRJ usklađena s međunarodnim standardima iz ove oblasti.
\end{abstract}

Ključne riječi: maloljetni učinitelji; minimalna granica krivične odgovornosti; mladi punoljetnici.

* Dr. sc. Vedad Gurda, izvanredni profesor, Univerzitet u Tuzli, Pravni fakultet; vedad.gurda@ untz.ba. 


\section{UVODNA RAZMATRANJA}

Općepoznata je činjenica kako maloljetnici, kao specifična kategorija učinitelja krivičnih djela, uživaju posebni pravni status u okrilju savremenog krivičnog prava. Taj status ogleda se u činjenici da se prema ovoj kategoriji učinitelja primjenjuju specifična pravila krivičnog prava, vezana za pitanja: a) krivnje (krivične odgovornosti) maloljetnika $i$ b) specifičnih krivično-pravnih mjera $i$ sankcija koje im se mogu izricati, ali i za pitanja c) posebnih organa koji postupaju s maloljetnicima u sukobu sa zakonom, d) osobene (krivične) procedure koju ti organi primjenjuju, te, na koncu, i posebnih pravila o e) zaštiti maloljetnika kao oštećenih u krivičnom postupku. Ratio ovakvog tretmana maloljetnika u sukobu sa zakonom svoja idejna ishodišta nalazi u naučnim spoznajama iz oblasti medicine, pedagogije, sociologije, te posebno psihologije, a koje ukazuju na činjenicu da je riječ o hipersenzibilnoj grupaciji nedoraslih osoba, koje se nalaze u procesu psihofizičkog razvoja, te koje je zbog osobenih karakteristika njihove ličnosti potrebno posebno krivično-pravno tretirati.

Osim maloljetnika, većina savremenih krivičnih zakonodavstava poznaje još dvije kategorije mladih osoba koje mogu ostvariti obilježja nekog krivičnog (protivpravnog) djela. Prvu kategoriju predstavljaju izuzetno mlade osobe, koje zbog svoje izrazite nezrelosti nemaju aktivni krivično-pravni subjektivitet, te su potpuno izuzete od odgovornosti i procesuiranja pred tijelima krivičnog pravosuđa i, u krivično-pravnom smislu, smatraju se djecom. ${ }^{1} \mathrm{~S}$ druge strane, većina savremenih krivično-pravnih sistema poznaje i grupaciju mlađih punoljetnika, kao osoba koje su dostigle formalno punoljetstvo i prema kojima se primjenjuju pravila općeg krivičnog prava, no uvažavajući činjenicu kako se procesi psihofizičkog i socijalnog sazrijevanja kod određenih mladih osoba nerijetko ne završavaju formalnim punoljetstvom, u tim sistemima se otvaraju perspektive djelimične primjene pojedinih posebnih pravila maloljetničkog krivičnog prava prema ovoj kategoriji „osoba u dobnoj tranziciji“.

Dodatno bi trebalo istaknuti kako navedeno kategoriziranje mladih učinitelja ne predstavlja potpunu novinu u savremenom krivičnom pravu, te da su se normativne tendencije uvažavanja uzrasta ove populacije susretale još u antičkom dobu. S tim u vezi, već u ranom kineskom pravu, djeca uzrasta do 7 godina smatrana su neodgovornim za svoje postupke, te su bila izuzeta od kažnjavanja. Učinitelji od 7 do 10 godina starosti su zbog posebnog statusa predlagani caru na pomilovanje, dok su

1 Treba napomenuti da kategorizacija mladih (nepunoljetnih) učinitelja krivičnih djela na one koji ne mogu odgovarati pred tijelima krivičnog pravosuđa (djeca) i krivično odgovorne (maloljetnici), koju poznaju zakonodavstva na području bivše Jugoslavije, nije općeprihvaćena. U uporednom pravu se susreću i drugačije kategorizacije. Primjera radi, zakonodavstva Bugarske i Rusije razlikuju kategorije maloljetnika, kao osoba ispod 14 godina koje nisu krivično odgovorne, te nepunoljetnih uzrasta 14-18 godina, koji se procesuiraju pred tijelima krivičnog pravosuđa. Vidi: Krassimir Kanev et al., „Bulgaria“ u: Juvenile Justice Systems in Europe: Current Situation and Reform Developments, eds. Frieder Dunkel et al. (Monchengladbach: Forum Verlag Godesberg, 2010.), 133, 140-141.

No, generalno, u uporednom pravu se osobe mlađe od 18 godina tretiraju kao maloljetnici (juveniles), odnosno kao djeca (prema Konvenciji o pravima djeteta), koje, zbog svoje nedoraslosti, uživaju poseban krivičnopravni status. 
za maloljetnike od 10 godina i više bile predviđene blaže kazne. ${ }^{2}$

Ovakve tendencije susreću se i u rimskom pravu iz doba Carstva, kada su uvedene prve odredbe o starosnom kategoriziranju mladih učinitelja krivičnih djela. ${ }^{3}$ Tako je Justinijanov kodeks iz 529. sadržavao pravila kojima se uređuju starosne granice krivično-pravnog maloljetstva, te je razlikovao tri kategorije mladih učinitelja krivičnih djela: (a) djecu do sedam godina (infantes), kao potpuno neodgovorne osobe koje se uopće ne mogu kažnjavati; (b) djecu od sedam do deset godina (infantiae proximi), za koju je propisivao izuzetnu kažnjivost onda kada se utvrdi da su sposobna za krivnju (doli capax), pri čemu je vrijedila presumptio iuris tantum o njihovoj nesposobnosti za krivnju, pa samim tim i krivičnu neodgovornost, te (c) maloljetnike od deset do četrnaest godina (pubertati proximi) za koje je vrijedila obrnuta pretpostavka - da su krivi dok se ne dokaže suprotno. ${ }^{4}$

Navedena pravila će imati utjecaja i na srednjovjekovna zakonodavstva, a moglo bi se ustvrditi da ona predstavljaju historijsko-pravno ishodište moderne podjele mladih osoba na djecu i maloljetnike, ${ }^{5} \mathrm{~s}$ tim da, kada je riječ o starosnim granicama nastupanja i prestanka krivično-pravnog maloljetstva, recentna uporednopravna rješenja su, ipak, nešto drugačija. Naime, od druge polovine XVIII, te posebno tokom XIX i XX stoljeća, dolazi do podizanja starosnih granica i humaniziranja maloljetničkog krivičnog prava, premda je i ova konstatacija tek djelimično tačna, s obzirom na to da su uporedno-pravna iskustva prilično šarolika. O tome će biti više govora u nastavku rada.

$\mathrm{Na}$ kraju uvodnih razmatranja treba napomenuti kako su starosne granice krivično-pravnog maloljetstva u domaćoj literaturi nerijetko označavane kao starosne granice krivične odgovornosti. Međutim, imajući u vidu da je izmjenama krivičnih zakonodavstava država iz regiona tokom zadnjih decenija termin krivična odgovornost, kao termin deklarativnog karaktera, napušten, te se umjesto njega upotrebljava termin krivnja, korištenje spomenute sintagme se čini pomalo nesuvislim. No, i pored spomenute legislativne novine, u ovom radu će se, nerijetko, koristiti i ova sintagma. To iz razloga što rad ima za cilj osvijetliti uporednopravne horizonte ovog pitanja, a u uporednom pravu o njemu se obično govori kao o starosnim granicama krivične odgovornosti (engl. age of criminal responsibility).

2 Olgica Matić, Ispitivanje ličnosti maloletnika kao osnov za određivanje vaspitne mere i mera tretmana u VP domovima (Beograd: Institut za kriminološka i sociološka istraživanja, 1974.), 30.

3 Dalida Rittossa, Melita Božičević Grbić, „Zakon o sudovima za mladež - reformski zahvati i praktične dileme“, Hrvatski ljetopis za kazneno pravo i praksu 19, br. 2 (2012): 617.

4 Ido Weijers, Thomas T. Grisso, „Criminal Responsibility of Adolescents: Youth as Junior Citizenship “ u: Reforming Juvenile Justice, eds. Josine Junger-Tas, Frieder Dunkel (DordrechtHeilderberg-London-New York: Springer, 2009.), 47.

5 Katja Filipčić, „Protislovja v razvoju koncepta odgovornosti mladoletnih prestupnikovov“, Zbornik znanstvenih rasprav, Pravna fakulteta Univerza v Ljubljani LXV, br. 1 (2005): 125. 


\section{KRITERIJI I MODELI UTVR円IVANJA KRIVIČNO-PRAVNOG MALOLJETSTVA}

U gotovo svim modernim zakonodavstvima krivično-pravni pojam maloljetnika se određuje na osnovu formalnog kriterija starosnog (kalendarskog) uzrasta učinitelja u vrijeme učinjenja krivičnog djela. Međutim, u literaturi se navodi kako bi se kao kriterij određivanja krivično-pravnog maloljetstva mogao koristiti i materijalni kriterij, kao kriterij stvarne zrelosti mladog čovjeka prema dostignutom stepenu biološke, psihološke ili socijalne zrelosti njegove ličnosti, neovisno od godina koje je stvarno navršio. ${ }^{6}$ Štaviše, prvom rješenju se sasvim opravdano prigovara da određivanje krivično-pravnog maloljetstva na temelju fiksnih granica kalendarskog uzrasta može predstavljati artificijelno i „mehaničko“ rješenje. Naime, iako kalendarski uzrast u dobroj mjeri korespondira sa stepenom biopsihičke i socijalne zrelosti, poznata je činjenica da ponekad mladi istog dobnog uzrasta ne dostižu jednak stepen navedene zrelosti. Osim toga, imajući u vidu činjenicu da u pojedinim zakonodavstvima određenje formalnih granica krivično-pravnog maloljetstva predstavlja rezultat djelovanja različitih historijskih, tradicijskih (religijskih), kriminalno-političkih i političkih faktora, pa čak i svojevrsnog ,pomodarstva“ $i$,,kopiranja“ rješenja iz drugih (razvijenih) zakonodavstava, a ne epilog naučno utemeljenog proučavanja procesa biopsihičkog i socijalnog sazrijevanja mladih u nacionalnim okvirima, pojedini autori se zbog svega navedenog zalažu za ukidanje starosnih granica. ${ }^{7}$

S druge strane, iako je primjena materijalnog kriterija, odnosno utvrđivanja stvarne zrelosti mlade osobe, realnija i ima veću naučnu utemeljenost, ona nije široko prihvaćena u praksi, zbog nekih praktičnih razloga. S tim u vezi, kao prva poteškoća koja onemogućava utvrđivanje stvarne zrelosti mladih vezana je za činjenicu da $u$ procesu sazrijevanja često dolazi do nesklada između tjelesne i duševne razvijenosti, s jedne strane, te socijalne zrelosti, s druge strane. ${ }^{8}$ Drugi, i, čini se, presudni razlog zašto primjena ovog modela nije zaživjela, jeste bojazan da bi zbog nepostojanja sigurnih kriterija i metoda za njegovo utvrđivanje moglo doći do različitih zloupotreba i arbitrarnosti od strane sudije ili drugog subjekta koji bi odlučivao u konkretnom slučaju. Na kraju, nedostatak kadrovskih i infrastrukturnih potencijala za potpunu opservaciju i procjenu dostignutog stepena biopsihičke i socijalne zrelosti mladih dodatno su limitirali oživotvorenje ovog modela u praksi. ${ }^{9}$

Upravo iz navedenih razloga, u većini zakonodavstava prihvaćen je formalni kriterij određenja krivično-pravnog maloljetstva, u smislu da su zakonom određene starosne granice unutar kojih se mladi učinitelji krivičnih djela tretiraju kao maloljetnici i uživaju već pominjane benefite specifičnog krivično-pravnog statusa. Pri tome, u uporednom pravu se susreću dva modela određenja tih granica. Prema prvom modelu, prihvaćenom u većini država SAD-a, te u izvjesnom broju latinoameričkih (Panama) i

6 Ante Carić, Mlađe osobe u kaznenom pravu (počinitelji i žrtve) (Zagreb: Pravni fakultet, 2002.), 19.

7 Žarko Jašović, Kriminologija maloletničke delinkvencije (Beograd: Institut za kriminološka i sociološka istraživanja, 2000.), 46.

8 Carić, Mlađe osobe u kaznenom pravu (počinitelji i žrtve), 19.

9 Milan Škulić, Maloletnici kao učinioci i žrtve krivičnih dela (Beograd: Dosije, 2003.), 80. 
muslimanskih zemalja (Saudijska Arabija, Jemen), određuje se samo gornja starosna granica, kojom se odvaja kategorija maloljetnika od odraslih učinitelja krivičnih djela. ${ }^{10}$ Donja starosna granica, kao granica nastupanja krivično-pravnog maloljetstva i odgovornosti, zakonom nije određena. Sud je u svakom konkretnom slučaju dužan da procijeni da li je neka mlada osoba u vrijeme učinjenja krivičnog djela posjedovala dovoljan stepen biopsihičke i socijalne zrelosti, da je bila sposobna razlikovati (protiv)pravnost i (ne)moralnost svog djela. Ukoliko je odgovor potvrdan, ona se ima tretirati krivično odgovornom za učinjeno krivično djelo (doli capax princip u angloameričkom pravu). ${ }^{11}$

$\mathrm{S}$ druge strane, u većini država prihvaćen je model dviju starosnih granica (donje i gornje).

\section{STAROSNE GRANICE KRIVIČNO-PRAVNOG MALOLJETSTVA}

Neovisno o tome koliko su mladi pojedini učinitelji krivičnih djela, društvo prema njihovom prestupničkom djelovanju ne može ostati indiferentno i nadležne društvene agencije moraju poduzeti određene oblike djelovanja prema njima. Donja starosna granica služi kao diferencirajući kriterij u određivanju stava da li je neka mlada osoba, koja je učinila krivično djelo, dostigla pretpostavljeni stepen minimalne zrelosti da bi bila procesuirana pred tijelima krivičnog pravosuđa ili će prema mladima, koji nisu dostigli granice krivično-pravnog maloljetstva, postupati neke druge agencije (npr. organi socijalne zaštite ili neka upravna tijela), koristeći mjere i instrumentarij reagiranja iz svoje nadležnosti, oslobođen represivnog kolorita $\mathrm{i}$ isključivo protektivne naravi.

U pojedinim zemljama ova granica je niska i iznosi svega šest ili sedam godina. U nekim od tih zemalja na izuzetno nisku granicu nastupanja krivične odgovornosti mladih osoba utječu religijski i tradicijski razlozi, ali se ovakva rješenja susreću i u zemljama gdje religija i tradicija nemaju veliki društveni utjecaj. ${ }^{12}$ Ipak, u posljednjih nekoliko decenija u pojedinim državama se bilježi trend podizanja ovih granica. Primjera radi, u Izraelu je ova granica 1977. podignuta s 9 na 13 godina, na Kubi 1979. s 12 na 16 godina, te u Argentini 1983. s 14 na 16 godina. Godinu dana kasnije u Kanadi, ona je pomjerena sa 7 na 12 godina, a 1987. i u Norveškoj sa 14 na 15 godina. ${ }^{13}$ Sličan trend se nastavlja i u prvoj deceniji XXI stoljeća, te je 2001. u Irskoj predmetna granica sa 7 podignuta na 12 godina, a iste godine se to desilo i u Španiji, gdje je ta granica pomjerena s 12 na 14 godina. ${ }^{14}$ Noviji primjer ovakvih tendencija na

10 Weijers, Grisso, Criminal Responsibility of Adolescents: Youth as Junior Citizenship, 52; Neal Hazel, Cros-National Comparison of Youth Justice (Youth Justice Board, 2008.), 30.

11 To znači da se u ovim zemljama za nastupanje krivičnopravnog maloljetstva i odgovornosti primjenjuje materijalni kriterij.

12 Ljiljana Radulović, „Maloletničko krivično pravo Engleske i Velsa - između „etosa brige i zaštite“ i „etosa odgovornosti i kažnjavanja“““, Anali Pravnog fakulteta u Beogradu 58, br. 1 (2010): 47.

13 Hazel, Cros-National Comparison of Youth Justice, 33.

14 Cristina Rechea Alberola, Ester Fernandez Molina, „Juvenile Justice in Spain: Past and Present“, Journal of Contemporary Criminal Justice 19, no. 4 (2003): 399. 
tlu Evrope bilježi se u Škotskoj, gdje je usvajanjem The Age of Criminal Responsibility Act-a iz 2019. godine predmetna starosna granica podignuta s 8 na 12 godina. ${ }^{15}$

Međutim, u uporednom pravu se mogu susresti i suprotne tendencije. Naime, usred činjenice da se u ulozi učinitelja teških krivičnih djela sve češće pojavljuju djeca ranog uzrasta, te uvjerenja kako mladi u modernom socijalnom ambijentu brže sazrijevaju, u pojedinim sredinama postoji pritisak političara, javnosti, ali i određenih profesionalnih krugova da se snize granice nastupanja krivično-pravnog maloljetstva ili da se uvede sistem „dvostrukog kolosijeka“. Kao primjer prve tendencije može se navesti englesko zakonodavstvo. Naime, tamo je do 1998. starosni minimum nastupanja krivično-pravnog maloljetstva i odgovornosti za većinu krivičnih djela (izuzev za teška krivična djela s elementima nasilja) bio 14 godina, kada je Crime and Disorder Act-om ta granica spuštena sa 14 na 10 godina za sva krivična djela. ${ }^{16}$ Također, u Panami je starosna granica 2010. smanjena sa 14 na 12 godina. ${ }^{17}$ Kao primjer druge tendencije može se navesti reforma zakonodavstva u Republici Irskoj, u kojoj je 2006. prihvaćen sistem „dvostrukog kolosijeka“, te je starosna granica za pojedina teška krivična djela (ubistvo, ubistvo bez predumišljaja, silovanje itd.) s 12 smanjena na 10 godina, dok je za druga krivična djela ostala na 12 godina. ${ }^{18}$ Slične legislativne novine dogodile su se 2012. i u Mađarskoj, kada je ta granica spuštena sa 14 na 12 godina, ali samo za teška krivična djela, dok je za lakša ostala nepromijenjena. ${ }^{19}$

Na kraju, u Gruziji je izmjenama krivičnog zakonodavstva iz 2007. donja granica krivično-pravnog maloljetstva za određena (teška) krivična djela bila smanjena sa 14 na 12 godina, da bi, u skladu s preporukama UN-ovog Komiteta za prava djeteta, u februaru 2010. ponovo vraćena na 14 godina. ${ }^{20}$ Slična situacija se dogodila i u Danskoj, gdje je 2010. granica s 15 bila snižena na 14 godina, da bi 2012. ponovo vraćena na 15 godina. $^{21}$

Kada je u pitanju gornja starosna granica, ona predstavlja starosni limit prestanka krivično-pravnog maloljetstva i otpočinjanja punoljetstva, te služi kao diferencirajući kriterij da li će se prema učinitelju krivičnog djela, zavisno od dostignutog uzrasta, primjenjivati maloljetničko krivično pravo, koje se zbog svoje protektivne naravi nerijetko označava i kao „kvazi krivično pravo“22 ili opće krivično pravo s elementima represije. U većini modernih zakonodavstava ova granica iznosi 18 godina. Ipak, u

15 Vidi: https://www.gov.scot/policies/youth-justice/raising-age-criminal-responsibility/ (30.4.2020.)

16 Radulović, Maloletničko krivično pravo Engleske i Velsa - između „etosa brige i zaštite“ $i$ „etosa odgovornosti i kažnjavanja“, 203

$17 \mathrm{https} / /$ archive.crin.org/en/home/what-we-do/policy/stop-making-children-criminals/stateslowering-age-criminal-responsibility.html (25. 4. 2020.)

18 Dermot Walsh, „Ireland“ u: Juvenile Justice Systems in Europe: Current Situation and Reform Developments, eds. Frieder Dunkel et al. (Monchengladbach: Forum Verlag Godesberg, 2010.), 724.

19 https://archive.crin.org/en/home/what-we-do/policy/stop-making-children-criminals/stateslowering-age-criminal-responsibility.html (25. 04. 2020.)

20 Ibid.

21 Ibid.

22 Stojanović, Zoran, Krivično pravo - opšti deo, 10. izd. (Beograd: Dosije, 2015.), 344. 
izvjesnom broju zemalja krivično-pravno punoljetstvo i nadležnost redovnih krivičnih sudova, koji primjenjuju opće krivično pravo, nastupa prije 18. godine. Naravno, za pretpostaviti je da u onim zemljama gdje su starosne granice nastupanja krivičnopravnog maloljetstva izuzetno niske i dobni limiti njegovog prestanka su nešto niži. Međutim, u uporednom pravu se mogu susresti i suprotni primjeri. No, o svemu tome će biti nešto više riječi u narednim poglavljima.

\section{PRIKAZ STAROSNIH GRANICA U UPOREDNOM KRIVIČNOM PRAVU}

\subsection{Starosna granica nastupanja krivično-pravnog maloljetstva}

Međunarodni dokumenti iz oblasti postupanja s maloljetnicima u sukobu sa zakonom, pored ostalih, sadrže i određene standarde vezane za pitanje starosne granice krivične odgovornosti. S tim u vezi, u odredbama člana 40, stav 3, Konvencije o pravima djeteta se ističe da će države potpisnice nastojati da podstiču donošenje zakona, postupaka, uspostavljanje organa i ustanova primjenjivih na djecu koja su optužena i za koju se tvrdi da su prekršila krivični zakon, te posebno da će promicati utvrđivanje najniže starosne granice ispod koje djeca ne mogu biti smatrana sposobnim za kršenje krivičnog zakona. Ova granica predstavlja na nacionalnom nivou prihvaćeni starosni prediktor minimalne intelektualne, emotivne i socijalne zrelosti mlade osobe da bi ona mogla odgovarati za učinjeno krivično djelo pred organima krivičnog pravosuđa. Prethodno je spominjano kako u većini država SAD-a, te u pojedinim latinoameričkim i muslimanskim zemljama, ta granica nije zakonom određena, dok nemamo saznanja da li je u nekim zemljama određena nekim smjernicama ili podzakonskim aktima. Međutim, ni konvencijska norma eksplicitno ne zahtijeva da najniža dob mora biti zakonom određena. Kao što ističu pojedini autori, ${ }^{23}$ imajući u vidu da ona omogućava krivičnu odgovornost maloljetnika i izricanje krivičnih sankcija, za koje vrijedi princip zakonitosti (legaliteta), onda takav princip treba vrijediti i za određivanje starosnih granica. Otuda smatramo da je navedena praksa u suprotnosti s duhom i standardima Konvencije. Ipak, u većini zemalja granica nastupanja krivično-pravnog maloljetstva (krivične odgovornosti) jeste određena. Pregled uporedno-pravnih rješenja u 90 zemalja širom svijeta sadržan je u narednom tabelarnom prikazu, preuzetom iz rada N. Hazela, ${ }^{24}$ koji je neznatno modificiran na osnovu novijih izmjena zakona u pojedinim državama, poput Škotske i Mađarske(*).

23 Reynald Ottenhof, „Criminal Responsibility of Minors in National and International Legal Order", International Review of Penal Law 75, 1 (2004): 59.

24 Hazel, Cross-National Comparison of Youth Juctice, 30. 
V. GURDA, Starosne granice krivično-pravnog maloljetstva u uporednom pravu Zbornik Pravnog fakulteta Sveučilišta u Rijeci, vol. 41, br. 3, 781-802 (2020)

Tabela 1. Starosne granice nastupanja krivično-pravnog maloljetstva

\begin{tabular}{|c|c|}
\hline Starosna granica & Država \\
\hline 6 godina & Meksiko, Sjedinjenje Američke Države \\
\hline 7 godina & $\begin{array}{l}\text { Barbados, Egipat, Indija, Jamajka, Kenija, Kipar, Kuvajt, Lihtenštajn, } \\
\text { Singapur, Tajland, Trinidad }\end{array}$ \\
\hline 8 godina & Kajmanska Ostrva, Grčka*, Libija, \\
\hline 9 godina & Filipini, Irak, Malta \\
\hline 10 godina & $\begin{array}{l}\text { Australija, Engleska i Vels, Južna Afrika, Malezija, Novi Zeland, } \\
\text { Namibija, Sjeverna Irska, Śvicarska, Republika Irska }\end{array}$ \\
\hline 12 godina & $\begin{array}{l}\text { Ekvador, Holandija, Honduras, Kanada, Kostarika, Liban, San Marino, } \\
\text { Turska, Škotska*, Mađarska* }\end{array}$ \\
\hline 13 godina & Alžir, Francuska, Izrael, Poljska, Senegal, Togo \\
\hline 14 godina & $\begin{array}{l}\text { Armenija }{ }^{25}, \text { Austrija, Azerbejdžan, Bjelorusija, Bosna i Hercegovina, } \\
\text { Bugarska, Hrvatska, Italija, Japan, Kina, Kazahstan, Koreja, Litvanija, } \\
\text { Makedonija, Mauricijus, Mongolija, Njemačka, Slovenija, Spanija, } \\
\text { Ukrajina, Zambija }\end{array}$ \\
\hline 15 godina & Češka, Danska, Finska, Island, Norveška, Slovačka, Švedska, Tanzanija \\
\hline 16 godina & $\begin{array}{l}\text { Andora, Argentina, Belgija, Čile, Estonija, Hong Kong, Kuba, Latvija, } \\
\text { Moldavija, Portugal, Rumunija, Rusija }\end{array}$ \\
\hline 18 godina & Kolumbija, Luksemburg \\
\hline Nije propisana & Bruneji, Panama, Saudijska Arabija, Sjedinjenje Američke Države \\
\hline
\end{tabular}

Sumirajući predočene rezultate, zaključujemo da je u određenom broju država donja starosna granica izuzetno niska i iznosi tek 6 ili 7 godina, kakva rješenja se susreću u Indiji, Singapuru, Barbadosu, Jamajci, Lihtenštajnu, Trinidadu, Kuvajtu, te u pojedinim državama u SAD-u i Meksiku. ${ }^{26}$ Istina, u SAD-u ovako niska granica nastupanja krivičnopravnog maloljetstva bilježi se u svega nekoliko država, poput Sjeverne Karoline (6), Njujorka (7), Merilenda (7) i Masačusetsa (7). U drugim državama ona je neznatno veća, te iznosi 8 (Arizona) ili 10 godina (Arkanzas,

25 Treba istači da u Rusiji i većini bivših sovjetskih republika (Armenija, Azerbejdžan, Bjelorusija, Kazahstan, Litvanija, Moldavija i Ukrajina) krivična odgovornost načelno nastupa sa 16 godina, izuzev za pojedina (uglavnom) teška krivična djela kada počinje sa 14 godina. Vidi: Don Cipriani, Children's Rights and the Minimum Age of Criminal Responsibility: A Global Perspective (Farhnam: Ashgate, 2016.), 98-108. S obzirom na postojanje dvije granice očigledno je da je Hazel kod ovih država primjenio različitu metodologiju evidentiranja te pojedine države premda posjeduju identična legislativna rješenja svrstao u različite starosne razrede.

26 U većini država u Meksiku predmetna starosna granica iznosi 11 ili 12 godina. Vidi: Milan Škulić, Maloletničko krivično pravo (Beograd: Pravni fakultet, 2011.) 275. 
Kolorado, Kanzas, Luizijana, Minesota, Misisipi, Pensilvanija, Južna Dakota, Teksas, Vermont i Viskonsin). ${ }^{27} \mathrm{U}$ preostalim državama, a kao što je prethodno istaknuto, granica nastupanja krivično-pravnog maloljetstva zakonom nije određena.

Ipak, najčešće, posebno u evropskim zemljama, uključujući i zemlje s prostora bivše Jugoslavije, predmetna starosna granica iznosi 14 godina. ${ }^{28}$ Naravno, s obzirom na kulturne, historijske, vjerske, političke i druge faktore koji su utjecali na dizajniranje starosnih granica u pojedinim zemalja, iluzorno je očekivati da postoji jedinstveno rješenje po ovom pitanju. ${ }^{29}$ To tim prije, jer ni međunarodni dokumenti ne insistiraju na uniformnom rješenju, niti eksplicitno određuju najnižu starosnu granicu koja bi bila međunarodno prihvatljiva. Međutim, Standardna minimalna pravila UN za maloljetničko pravosuđe (Pekinška pravila) uspostavljaju standard po kojem u onim pravnim sistemima koji poznaju minimalni uzrast za krivičnu odgovornost maloljetnika, ta granica neće biti vezana za suviše rani uzrast, a imajući u vidu emotivnu, mentalnu i intelektualnu zrelost takve osobe (vidi: pravilo 4.1). Također, i Evropskim pravilima o sankcijama i mjerama izrečenim maloljetnim učiniteljima krivičnih djela (Rec (2008)11) (osnovni princip br. 4). i Smjernicama o pravosuđu prilagođenom djeci iz 2010. godine (čl. 23.), koji predstavljaju soft law instrumente Vijeća Evrope, ustanovljen je princip da starosna granica krivične odgovornosti neće biti suviše niska, s tim da ovi evropski instrumenti utvrđuju i standard da ta granica mora biti određena zakonom. Naravno, s obzirom da prvonavedeni nije kvantitativno preciziran, ostaje dilema kako uopće razumijevati pomenuti standard. Čak se i Evropski sud za ljudska prava u svojim odlukama suzdržavao od fiksnog određivanja međunarodno prihvatljive starosne granice krivične odgovornosti. ${ }^{30}$ Međutim, jedan od zaključaka 17. svjetskog kongresa Međunarodnog udruženja za kazneno pravo (International Association of Penal law), održanog 2004. u Pekingu, bio je da minimalna starosna granica nastupanja krivične odgovornosti na internacionalnom

27 Weijers, Grisso, „Criminal Responsibility of Adolescents: Youth as Junior Citizenship“ “ Reforming Juvenile Justice, eds. Josine Junger-Tas, Frieder Dunkel, 2009:52.

28 Iscrpan pregled recentnih starosnih granica krivično-pravnog maloljetstva na području Evrope dostupan je u radu Dunkel et al. (eds.), Juvenile Justice Systems in Europe: Current Situation and Reform Developments, 1821-1822.

29 Cipriani, Children's Rights and the Minimum Age of Criminal Responsibility: A Global Perspective, 4.

30 Evropski sud za ljudska prava je o granicama nastupanja krivične odgovornosti raspravljao u predmetu $T$. i $V$. protiv Ujedinjenog Kraljevstva (odluka od 16. 12. 1999. poznata kao Bulger case), u kojem se, između ostalog, raspravljalo da li krivično gonjenje i utvrđena odgovornost apelanata za djela koja su počinili u dobi od 10 godina predstavlja nehumano i ponižavajuće postupanje u smislu čl. 3. Evropske konvencije o ljudskim pravima. Sud je našao da u konkretnom slučaju nisu povrijeđene odredbe Konvencije, pravdajući to činjenicom da među zemljama članicama Vijeća Evrope ne postoji općeprihvaćeni standard o minimalnoj dobi nastupanja krivične odgovornosti. Sud je konstatirao kako je granica od 10 godina u Engleskoj i Velsu zaista niža u odnosu na većinu zemalja članica Vijeća Evrope, ali da postoje i zemlje u kojima je ta granica još niža. Uz to se navodi da ni relevantni međunarodni dokumenti ne propisuju precizni dobni standard o nastupanju krivične odgovornosti. Vidi: Janet Dine, James Gobert, William Wilson, Cases and Materials on Criminal Law (Oxford University Press, 2010.), 427. 
nivou ne treba da bude niža od 14 godina. ${ }^{31}$ Također, i Parlamentarna skupština Vijeća Evrope u svojoj rezoluciji Maloljetničko pravosuđe prilagođeno djeci: od retorike do stvarnosti (br. 13511) iz 2014. pozvala je države članice da u svojim zakonodavstvima uspostave minimalnu granicu krivične odgovornosti koja neće biti niža od 14 godina (čl. 6.2.). Na kraju, i Komitet UN-a za prava djeteta u svom najnovijem Generalnom komentaru br. 24 o pravima djece u sistemu pravosuđa za djecu iz 2019. godine (par. 22) poziva države članice da podignu minimalnu dob nastupanja krivične odgovornosti na 14 godina.

Insistiranjem na principu da minimalna granica krivične odgovornosti ne bude vezana za suviše rani uzrast, nastoji se izbjeći mogućnost procesuiranja potpuno nezrelih mladih osoba pred organima krivičnog pravosuđa, s obzirom na to da je takav oblik društvene reakcije, čak i kada je u pitanju maloljetničko krivično pravosuđe sa svim njegovim posebnostima, uglavnom represivniji u odnosu na reakciju koju primjenjuju neke druge društvene agencije (najčešće one iz oblasti socijalne zaštite i porodičnog zakonodavstva) prema učiniteljima mlađim od tog uzrasta koji nisu krivično odgovorni, odnosno djeci.

\subsection{Mehanizmi ublažavanja negativnih efekata niskih starosnih granica nastupanja krivično-pravnog maloljetstva}

Činjenica da pojedina zakonodavstva propisuju izrazito niske granice uzrasta od kada mlade osobe mogu biti procesuirane pred organima krivičnog pravosuđa svakako da ne predstavlja neko progresivno rješenje, no samo na temelju toga ne može se a priori izvoditi zaključak da je krivično-pravni status maloljetnika u nekom nacionalnom zakonodavstvu loš. Naime, takva zakonodavstva uvode određena rješenja kojima se značajno relativiziraju negativni efekti mogućnosti krivičnog procesuiranja osoba u ranoj životnoj dobi, te na taj način značajno humaniziraju i unapređuju sveukupni pravni status maloljetnika u sukobu sa zakonom.

S tim u vezi, smatra se da u zemljama gdje su granice krivične odgovornosti dosta niske, ali postoje široke mogućnosti vansudskog (engl. diversion) reagiranja na delinkventna ponašanja maloljetnika koji su dostigli minimalno traženi uzrast, primjena vansudskih (alternativnih) modela reagiranja zbog njihovog nerepresivnog karaktera znatno ublažava negativne efekte niskih granica nastupanja krivične odgovornosti. Tako, premda je na Novom Zelandu granica relativno niska i iznosi 10 godina, njen značaj je relativiziran činjenicom da u ovoj zemlji postoje izuzetno razvijeni mehanizmi vansudskog okončanja maloljetničkih krivičnih predmeta kroz primjenu policijske diverzije ili tzv. konferencija porodičnih grupa (Family Group Conferences), tako da u praksi izuzetno mali broj maloljetnih učinitelja uopće i bude procesuiran pred sudovima (za mlade). ${ }^{32}$ Naime, povodom lakših krivičnih djela, te ukoliko se radi o maloljetniku koji je po prvi put učinio krivično djelo, policijski službenik obično ne inicira krivično gonjenje, već takvom maloljetniku izriče

31 Ottenhof, ,Criminal Responsibility of Minors in National and International Legal Order “, 57.

32 Katja Kristina Wiese, Juvenile Justice: A Comparison Between The Laws New Zealand and Germany, thesis (Christchurch, University of Canterbury, 2007.), 173. Pristup 10. juni 2020. www.http//ir.canterbury.ac.nz, 
upozorenje ili, pak, sačinjava tzv. diverzioni plan, koji predstavlja listu naloga koje maloljetnik treba dobrovoljno izvršiti (npr. nadoknaditi štetu oštećenom, ponuditi izvinjenje itd.). Ukoliko maloljetnik dobrovoljno realizira postavljene naloge takav predmet maloljetnog prestupnika ne ide $\mathrm{u}$ fazu formalnog optuženja i suđenja. ${ }^{33}$ Ipak, ono po čemu je najviše prepoznatljiv sistem maloljetničkog pravosuđa na Novom Zelandu jesu konferencije porodičnih grupa, kao alternativni forum u okviru kojeg se moraju raspraviti i najteži slučajevi maloljetničke delinkvencije (osim ubistva) prije nego što, eventualno, dođu pred sud za maloljetnike. ${ }^{34}$ Kao rezultat svoga rada, konferencija donosi preporuke ili uputstva za maloljetnog učinitelja, a najčešće se sačinjava plan po kojem će on postupati. Plan obavezno sadrži: a) obavezu maloljetnika da se izvini žrtvi; b) način na koji će biti nadoknađena prouzrokovana šteta; c) način kako da se otklone uzroci delinkventnog ponašanja; d) određivanje osoba i subjekata koji će pomagati maloljetniku u njegovoj implementaciji. Ukoliko maloljetnik realizira određene naloge i uputstva, predmet se neće ni upućivati sudu za maloljetnike radi krivičnog procesuiranja. ${ }^{35} \mathrm{U}$ literaturi se navodi da se tokom godina čak oko $80 \%$ maloljetničkih krivičnih predmeta okončavalo primjenom nekog od vansudskih oblika postupanja s maloljetnicima u sukobu sa zakonom, dok je tek približno svaki peti maloljetnički krivični predmet upućivan sudu radi procesuiranja. ${ }^{36}$

Slična je situacija i u Škotskoj, gdje je granica doskora bila 8, a sada je 12 godina. No, maloljetni učinitelji uzrasta do 16 godina se vrlo rijetko procesuiraju pred organima krivičnog pravosuđa (sudovima), već se postupak vodi pred alternativnim administrativnim forumima, poznatim kao Children's Panel-i. ${ }^{37}$

Iako granica nastupanja krivično-pravnog maloljetstva u državama s prostora bivše Jugoslavije nije suviše niska i iznosi 14 godina, sva maloljetnička krivična zakonodavstva u tim državama otvaraju široke perspektive primjene različitih alternativnih (diverzionih) mjera kojima se dodatno relativizira značaj te starosne granice. S tim u vezi, sva pomenuta zakonodavstva nude mogućnosti izbjegavanja pokretanja i vođenja krivičnog postupka prema maloljetniku primjenom načela oportuniteta krivičnog gonjenja, kao i različitih alternativnih mjera, poput posebnih obaveza određenih od strane državnog odvjetnika na temelju uvjetovane svrhovitost $i$ u Hrvatskoj, policijskog upozorenja i odgojnih preporuka u Bosni i Hercegovini, vaspitnih naloga u Srbiji, opomene i vaspitnih naloga u Crnoj Gori, mjera poravnanja (medijacije) ili odgođenog krivičnog gonjenja u Sloveniji, te mjera posredovanja $i$ poravnanja ili uslovnog odgađanja pokretanja krivičnog postupka u Sjevernoj

33 Gabrielle Maxwell, Jeremy Robertson, Tracy Anderson, Police Youth Diversion - Final Report, 2002., 42-43.

34 Konferencijom rukovodi specijalizirani socijalni radnik (eng. youth justice coordinator) i u njoj, pored maloljetnog učinitelja i žrtve, kao i članova njihovih porodica, obavezno učestvuju još predstavnik specijalizirane policije za mlade i advokat za mlade. Radu konferencije može prisustvovati i predstavnik centra za socijalni rad, ali i svaka druga osoba koju zainteresirane strane predlože.

35 Wiese, Juvenile Justice: A Comparison Between The Laws New Zealand and Germany, 210217.

36 Maxwell, Robertson, Anderson, Police Youth Diversion - Final Report, 42.

37 Raymond Arthur, Young Offenders and the Law: How the Law Responds to Youth Offending (Abingdon: Routledge, 2010.) 56. 


\section{Makedoniji.}

Drugi mehanizam pomenutog relativiziranja vezan je za činjenicu da su maloljetničke sankcije edukativnog ili rehabilitativnog karaktera (odgojne mjere i slične sankcije) po svojoj sadržini dosta slične mjerama koje prema mladim učiniteljima koji nisu dostigli uzrast krivične odgovornosti primjenjuju organi socijalne zaštite ili druge društvene agencije nadležne za postupanje s ovom kategorijom učinitelja. Stoga se praktični značaj predmetnih starosnih granica vidno relativizira u onim zemljama koje poznaju rješenje da se mlađim kategorijama krivično odgovornih maloljetnika mogu izricati isključivo sankcije edukativne ili rehabilitativne naravi, dok se kazne, i to posebno one institucionalnog karaktera, mogu izricati isključivo starijim skupinama maloljetnika.

Kao primjer navedenog, može se istaći maloljetničko krivično zakonodavstvo Švicarske, u kojem je posljednjom reformom iz 2007. granica nastupanja krivične odgovornosti podignuta na 10 godina, no za evropske prilike je još uvijek izuzetno niska. Međutim, švicarsko zakonodavstvo poznaje rješenje prema kojem se maloljetnim učiniteljima uzrasta 10-14 godina, iako su krivično odgovorni, mogu izricati isključivo edukativne mjere, kao što su nadzor, lična briga i nadzor, ambulantni tretman (za maloljetnike koji imaju probleme s mentalnim zdravljem), smještaj u edukativnoterapeutsku ustanovu otvorenog tipa, te smještaj u ustanovu zatvorenog tipa, dok se novčana kazna i kazna maloljetničkog zatvora izriče jedino maloljetnicima u dobi 15-18 godina. ${ }^{38}$

Kao što je prethodno istaknuto, u svim državama s ex-jugoslavenskih prostora krivična odgovornost nastupa sa 14 godina, s tim da maloljetnicima uzrasta od 14 do 16 godina (mlađi maloljetnici) sudovi mogu izricati isključivo odgojne (vaspitne) mjere, dok se maloljetnički zatvor, kao specifična kazna lišenja slobode maloljetnika, može izricati isključivo maloljetnim učiniteljima od navršenih 16 do navršenih 18 godina (stariji maloljetnici). ${ }^{39}$

Treći mehanizam relativiziranja značaja starosne granice predstavlja primjena sistema tzv. „dvostrukog kolosijeka“, gdje se, u zavisnosti od apstraktne težine učinjenog krivičnog djela, propisuju različite granice od kada mlade osobe mogu za ta djela odgovarati pred tijelima krivičnog pravosuđa. S tim u vezi, prema Krivičnom zakonu Ruske Federacije (čl. 20) granica nastupanja krivične odgovornosti je 16 godina, izuzev za određena krivična djela, poput, primjera radi, ubistva, teške tjelesne povrede, silovanja, terorizma itd., za koja se može krivično odgovarati već s navršenih 14 godina. Model „dvostrukog kolosijeka“ nastupanja krivične odgovornosti od 16 i za pojedina (uglavnom teška) krivična djela od 14 godina prihvaćen je i u drugim postsovjetskim državama, poput: Armenije, Azerbejdžana, Bjelorusije, Kazahstana, Kirgistana, Litvanije, Moldavije, Tadžikistana, Turkmenistana i Ukrajine, ali i Mongoliji, ${ }^{40}$ te već spominjanim Irskoj i Mađarskoj.

38 Dieter Hebeisen, „Switzerland“ u: Dunkel, Grzywa, Horsfield, Pruin, (eds.), Juvenile Justice Systems in Europe: Current Situation and Reform Developments, 1373.

39 Vedad Gurda, „Osnovna obilježja zakonske i sudske politike primjene kazne maloljetničkog zatvora u Bosni i Hercegovini i uporednom krivičnom pravu i praksi“", Zbornik radova Pravnog fakulteta u Rijeci 36, 2 (2015): 791-793.

40 Cipriani, Children's Rights and the Minimum Age of Criminal Responsibility: A Global 
Istovremeno, u nekim državama (npr. Australija, Filipini, San Marino, Rumunija itd.) egzistira nešto drukčiji model dviju granica nastupanja krivične odgovornosti, pri čemu prva (niža) predstavlja granicu od kada mlada osoba može odgovarati ukoliko se utvrdi i dokaže da je tempore criminis bila dovoljno zrela i sposobna razlikovati (protiv)pravnost i (ne)dopuštenost svog djela (doli capax) ili da je postupala s razborom (discernementom), dok druga (viša) predstavlja granicu nastupanja apsolutne krivične odgovornosti, te se razbor ili sposobnost snošenja krivnje (doli capax) apsolutno pretpostavljaju i ne treba ih utvrđivati. ${ }^{41}$ Zanimljivo je da je Komitet UN za prava djeteta u svom Generalnom komentaru br. 24. iz 2019. zauzeo stajalište da rješenja koja uključuju primjenu dviju starosnih granica nastupanja krivične odgovornosti maloljetnika, bilo povodom krivičnih djela različite težine ili u kontekstu doli (in) capax doktrine, nisu prihvatljiva, te pozvao države potpisnice da napuste takvu praksu i odrede jednu starosnu granicu od kada maloljetnici mogu odgovarati za kršenje krivičnog zakona (par. 25-27). Maloljetnička krivična zakonodavstva s exjugoslavenskih prostora propisuju samo jednu starosnu granicu nastupanja krivičnopravnog maloljetstva, te su po tom pitanju kompatibilna sa stajalištima Komiteta UN za prava djeteta.

\subsection{Starosna granica prestanka krivično-pravnog maloljetstva}

Kada su, pak, u pitanju starosne granice prestanka krivično-pravnog maloljetstva i nastupanja krivično-pravnog punoljetstva (criminal majority), kao uzrasta temeljem kojeg se pretpostavlja da je učinitelj dostigao potpunu zrelost, te je stoga sposoban odgovarati u punom kapacitetu pred tijelima općeg krivičnog pravosuđa, pojedina uporedno-pravna rješenja se mogu pratiti na temelju sljedeće tabele.

Tabela 2. Starosne granice krivično-pravnog punoljetstva ${ }^{42}$

\begin{tabular}{|l|l|l|l|l|l|}
\hline Država & $\begin{array}{c}\text { Starosna } \\
\text { granica }\end{array}$ & \multicolumn{1}{|c|}{ Država } & $\begin{array}{c}\text { Starosna } \\
\text { granica }\end{array}$ & \multicolumn{1}{|c|}{ Država } & $\begin{array}{c}\text { Starosna } \\
\text { granica }\end{array}$ \\
\hline Argentina & 18 & Holandija & $(16 / 18) 21$ & Namibija & 18 \\
\hline
\end{tabular}

Perspective, 98-108.

41 Primjera radi, u Indiji je prva granica vezana za uzrast od 7, a druga od 12 godina, dok se u Australiji prva granica odnosi na dob od 10, a potonja od 14 godina. Također, i u Maleziji mlade osobe za učinjena krivična djela mogu odgovarati već s 10 godina, ukoliko se utvrdi da su tempore criminis bile doli capax, dok se apsolutno pretpostavlja da su s 12 godina sve osobe načelno sposobne za snošenje krivnje, odnosno da su krivično odgovorne. Cipriani, Children's Rights and the Minimum Age of Criminal Responsibility: A Global Perspective, 98-108.

42 Navedeni tabelarni prikaz je preuzet iz spomenutog rada Hazela. Međutim, podaci koji se odnose na pojedine evropske zemlje, a koje navodi ovaj autor, ne podudaraju se sa podacima u radu Dunkel et al., (eds.), str. 1821-1822. Imajući u vidu da potonji rad predstavlja jedno od najnovijih istraživanja iz ove oblasti, mi smo u tabelu preuzetu od Hazela dodali i podatke iz datog rada. Isti su prikazani u zagradi (npr. (18). U većini slučajeva starosne granice koje navodi Hazel su nešto veće i može se pretpostaviti da je on u konkretnom slučaju predmetnim granicama obuhvatio i kategoriju mlađih punoljetnih osoba. 


\begin{tabular}{|l|l|l|l|l|l|}
\hline Australija & 17 & Hrvatska & $(18) 21$ & Norveška & 18 \\
\hline Austrija & 18 & Indija & 18 & Novi Zeland & $17 / 18$ \\
\hline Barbados & 16 & Irska & 18 & Njemačka & $18 / 21$ \\
\hline Bjelorusija & 16 & Izrael & 18 & Poljska & 17 \\
\hline Belgija & 18 & Italija & 18 & Rumunija & $(18 / 20) 21$ \\
\hline Bosna & 18 & Jamajka & 14 & Rusija & 18 \\
\hline Češka R. & 18 & Japan & 20 & SAD & $15-17$ \\
\hline Danska & 18 & Južnoafrič. R. & 18 & Singapur & 12 \\
\hline Egipat & 18 & Kanada & 18 & Sj. Irska & 18 \\
\hline Engl. i Vels & 18 & Kajmans. O. & 17 & Slovačka & 18 \\
\hline Estonija & $18 / 20$ & Kina & 25 & Slovenija & 18 \\
\hline Filipini & 15 & Kuba & 16 & Škotska & $16 / 18$ \\
\hline Finska & $(18) 20$ & Latvia & 18 & Španija & $(18) 21$ \\
\hline Francuska & 18 & Litvanija & 18 & Švedska & $18 / 21$ \\
\hline Grčka & $(18) 21$ & Mađarska & 18 & Švicarska & 18 \\
\hline Honduras & 18 & Makedonija & 16 & Turska & 18 \\
\hline Hong Kong & 20 & Moldavija & 16 & Ukrajina & 18 \\
\hline
\end{tabular}

U najvećem broju zemalja prestanak posebnog krivično-pravnog statusa, svojstvenog kategoriji maloljetnih učinitelja, i nastupanje krivično-pravnog punoljetstva, vezan je za uzrast od 18 godina. Kao što se može vidjeti iz prezentiranog tabelarnog prikaza takvo rješenje je prihvaćeno i u zakonodavstvima država s exjugoslavenskih prostora: Bosni i Hercegovini, Hrvatskoj i Sloveniji, a na identičan način je starosna granica definirana i u legislativama Crne Gore, Makedonije i Srbije. ${ }^{43}$ Predmetno rješenje djelimično korespondira i s Konvencijom o pravima djeteta, kao pravnom mehanizmu kojim se psihofizički i socijalno nezrelim osobama nastoji osigurati zadovoljavajući stepen pravne zaštite. Naime, za potrebe Konvencije, pojmom „dijete“ se označavaju osobe uzrasta do 18 godina, što, dakle, uključuje i pojam „maloljetnika“, onako kako se on upotrebljava u uporednom krivičnom pravu i međunarodnim dokumentima iz oblasti maloljetničkog pravosuđa. Ipak, valja napomenuti da takvo određenje starosne kategorije djeteta ne predstavlja općeobavezujući međunarodni standard, već više ima instruktivno značenje. ${ }^{44}$ No, imajući u vidu da Konvencija sublimira pricipe i dobru praksu kojih se ne bi trebala odreći niti jedna civilizirana zajednica, starosne granice prestanka posebnog krivično-

43 Škulić, Maloletničko krivično pravo, 272-273.

44 „U ovoj Konvenciji dijete znači svako ljudsko biće mlađe od 18 godina, osim ako se po zakonu koji se primjenjuje na dijete punoljetnost ne stječe ranije“"(čl. 1. Konvencije). 
pravnog statusa i otpočinjanja krivično-pravnog punoljetstva u pojedinim zemljama se čine neprihvatljivo niskim. Tu, prije svega, mislimo na rješenja koja postoje u Singapuru (12) i Jamajki (14), ali i Filipinima i pojedinim državama SAD-a, gdje starosne granice pune krivične odgovornosti otpočinju nakon 15 godina.

Ipak, treba naglasiti da u SAD-u tek u dvije države (Njujork i Sjeverna Karolina) granica prestanka krivično-pravnog maloljetstva i nastupanja krivično-pravnog punoljetstva otpočinje nakon navršenih 15 godina, u deset (Ilinois, Džordžija, Luizijana, Masačusets, Mičigen, Mizuri, Nju Hempšir, Južna Karolina, Teksas i Viskonsin) ona otpočinje nakon navršenih 16 godina, a u ostalim nakon 17 godina. ${ }^{45}$

\subsection{Mehanizmi relativiziranja značaja starosne granice prestanka krivično-pravnog maloljetstva}

Starosna granica prestanka krivično-pravnog maloljetstva i nastupanja krivičnopravnog punoljetstva nema apsolutno značenje, te se u uporednom pravu susreću određeni instituti kojima se relativizira značaj date starosne granice. S tim u vezi, u pojedinim državama značaj odnosne starosne granice relativiziran je mogućnošću upućivanja maloljetnih učinitelja (uglavnom težih) krivičnih djela $\mathrm{k}$ sudovima opće nadležnosti (,sudovima za odrasle“), odnosno mogućnošću primjene općeg krivičnog prava prema maloljetnicima i prije prestanka nominalnog krivično-pravnog maloljetstva (engl. transfer, weiver). U većini država koje poznaju navedeni institut mogućnosti njegove primjene vežu se za uzrast od 14 (Kanada), ${ }^{46} 15$ (Poljska) ${ }^{47}$ ili 16 godina (Belgija, Holandija, ${ }^{48}$ Indija $^{49}$ ), no u pojedinim državama SAD-a, te Engleskoj i Velsu ${ }^{50}$ ka sudovima opće nadležnosti mogu se transferirati i maloljetnici uzrasta od samo 10 godina.

Istina, u SAD-u k sudovima opće nadležnosti maloljetnici uzrasta od 10 godina se mogu transferirati samo u dvije države (Kanzas, Vermont), dok je u drugim zakonodavstvima data starosna granica nešto veća, te u tri države (Kolorado, Misuri, Montana) iznosi 12 godina, u šest (Ilinois, Misisipi, Nju Hempšir, Njujork, S. Karolina, Vajoming) 13 godina, u petnaest (npr. Alabama, Kalifornija, Mičigen, Teksas, Virdžinija) 14 godina, te u jednoj (Novi Meksiko) 15 godina. Međutim, u čak 23 države, kao što su, primjera radi, Arizona, Vašington, Florida, Karolina, Pensilvanija itd., minimalni uzrast za upućivanje maloljetnika k sudovima opće

45 Childhood and Adolescence in Society: Selections from CQ Researcher (London: Sage Publications, 2012.), 180.

46 Nicholas Bala, Julian V. Roberts, Canada's Juvenile Justice System: Promoting CommunityBased Responses to Youth Crime u: Josine Junger - Tas, Scott H. Decker (eds.), International Handbook of Juvenile Justice, 58-59.

47 Barbara Stando-Kavecka, Poland u: Scott H. Decker, Nerea Marteache (eds.), International Handbook of Juvenile Justice, Second Edition (Vienna: Springer, 2017.), 350.

48 Weijers, Nuytiens, Christiaens, Transfer of Minors to the Criminal Court in Europe: Belgium and the Netherlands, 107.

49 Hussain M. Muzaffar, „Age of Criminal Responsibility and the Child Criminal Justice: Imperatives of Developmental Model of Juvenile Justice for India“, Fiat Iustitia, 2 (2017): 222.

50 Weijers, Nuytiens, Christiaens, Transfer of Minors to the Criminal Court in Europe: Belgium and the Netherlands, 108. 
nadležnosti zakonom nije određen, tako da je teorijski moguće pred sudovima opće nadležnosti procesuirati i maloljetnike mlađe od 10 godina. ${ }^{51}$

U ovim zemljama primjena općeg krivičnog prava i transfer maloljetnika ka redovnim sudovima opravdava se tezom da se jedino putem ovog instituta mogu ostvariti efekti generalne prevencije, te da imajući u vidu činjenicu kako maloljetničko krivično pravo ne predstavlja adekvatan i primjeren odgovor na „teže slučajeve“ maloljetničke delinkvencije, transfer služi kao svojevrsni „sigurnosni ventil.“ No, ukoliko se pođe od općeprihvaćene premise da starosna granica krivičnopravnog punoljetstva predstavlja na nacionalnom nivou pretpostavljeni kriterij nečije zrelosti kao preduvjeta za punu krivičnu odgovornost, primjenom spomenutog instituta dolazi se u kontradiktornu i logički neodrživu situaciju. Naime, teško je prihvatiti da jedan te isti maloljetnik koji je učinio „lakše“ krivično djelo ili djelo „,srednje“ težine nije dostigao punu zrelost kao prediktor potpune krivične odgovornosti, dok je u slučaju „teških" krivičnih djela potpuno krivično odgovoran kao i odrasle osobe. Osim toga, upućivanjem maloljetnika ka sudovima za odrasle potkopava se suvremeni koncept o posebnom (krivično)pravnom statusu maloljetnih učinitelja krivičnih djela. ${ }^{52}$ Stoga je Komitet UN o pravima djeteta u svom Generalnom komentaru br. 10 iz 2007. i br. 24 iz 2019. godine preporučio ukidanje svih odredbi koje dozvoljavaju da učinitelji uzrasta ispod 18 godina budu tretirani kao odrasli, a u cilju da se osigura potpuna i nediskriminatorna primjena posebnih odredbi maloljetničkog (krivičnog) prava na sve mlade osobe ispod 18 godina starosti. ${ }^{53}$

Osim navedenog, u uporednom pravu se susreće i drugi način relativiziranja predmetne starosne granice, koji ima potpuno suprotne efekte. Naime, mnoga istraživanja su pokazala da se procesi psihofizičkog sazrijevanja, karakteristični za period puberteta, ne završavaju s osamnaest godina, već da traju i dalje, tako da značajan broj savremenih zakonodavstava poznaje mogućnost da i učinitelji koji starosno nadilaze dobne granice krivično-pravnog maloljetstva i spadaju u zakonsku kategoriju punoljetnih učinitelja, do određenog uzrasta mogu uživati posebni krivičnopravni tretman, sličan tretmanu maloljetnika u sukobu sa zakonom. Naravno, u pitanju je kategorija učinitelja koji se nalaze u periodu životne tranzicije iz mladalaštva $u$ punoljetstvo, a koja se obično označava kao kategorija mlađih punoljetnih učinitelja.

Ovakvo rješenje podržavaju, kako međunarodni, tako i supranacionalni dokumenti iz oblasti postupanja s maloljetnicima u sukobu sa zakonom. I većina evropskih zemalja, uključujući i zemlje s prostora bivše Jugoslavije, sadrži legislativna rješenja kojima se na određeni način uvažavaju osobenosti lica koja su neznatno zakoračila u doba nominalnog punoljetstva, bilo da u okviru maloljetničkog (krivičnog) zakonodavstva propisuju mogućnosti primjene specifičnih maloljetničkih sankcija (npr. odgojne mjere) i prema mlađim punoljetnicima ili, pak, u okviru općeg

51 Andrew Cherry, Valentina Baltag, Mary Dillon, (eds.), International Handbook on Adolescent Health and Development: The Public Health Response (Cham: Springer International, 2017.), 244.

52 Ineke Pruin, The Scope of Juvenile Justice Systems in Europe u: Dunkel et al., (eds.), Juvenile Justice Systems in Europe: Current Situation and Reform Developments, 1544.

53 Franklin E. Zimring, Maximo Langer, David S. Tanenhaus, Juvenile Justice in Global Perspective (New York-London: New York University Press, 2015.), 32. 
krivičnog zakonodavstva normiraju da će sankcije općeg krivičnog prava, kada se budu izricale mlađim punoljetnicima, biti dodatno ublažene ${ }^{54}$ ili pak primjenjuju oba ova modela. Tek manji broj zemalja, poput Belgije, Bugarske, Estonije, Latvije, Španije, Turske i Ukrajine, ${ }^{55}$ nemaju posebna pravila vezana za mlađe punoljetnike, no za očekivati je da će i one u nekoj budućoj reformi uvesti ovakvo rješenje, kako mlađi punoljetnici ne bi bili izgubljeni u tranziciji.

\section{ZAKLJUČ AK}

Starosne granice krivično-pravnog maloljetstva predstavljaju formalni (dobni) okvir unutar kojeg se određene mlade i nedorasle osobe u savremenom uporednom krivičnom pravu smatraju maloljetnicima, te koje, zbog svoje nedoraslosti unutar ove grane prava, uživaju posebni krivično-pravni status. Kada je riječ o definiranju starosne granice nastupanja krivično-pravnog maloljetstva, uporedno-pravna rješenja su različita. U nekim je državama ova granica prilično niska i iznosi svega šest ili sedam godina, dok u većini evropskih država ona iznosi četrnaest godina, a kakvo rješenje prihvataju i zakonodavstva država iz regiona bivše SFRJ. Konvencija UN o pravima djeteta i drugi međunarodni dokumenti predviđaju da ova granica neće biti suviše niska, ali je kvantitativno ne određuju. No, Komitet UN o pravima djeteta u svom Generalnom komentaru br. 24 iz 2019. i Parlamentarna skupština Vijeća Evrope u svojoj rezoluciji Maloljetničko pravosuđe prilagođeno djeci: od retorike do stvarnosti (br. 13511) iz 2014. pozivaju države članice da podignu minimalnu dob nastupanja krivične odgovornosti na 14 godina.

Značaj ove starosne granice u uporednom pravu se relativizira kroz primjenu alterantivnih (diverzionih) mjera ili propisivanje dviju granica nastupanja krivičnopravnog maloljetstva, kao i kroz određivanje veće starosne granice za izricanje kazni lišenja slobode u odnosu na ovu starosnu granicu. Zakonodavstva država iz regiona u skladu s međunarodnim standardima otvaraju perspektive relativiziranja značaja te starosne granice kroz mogućnosti vansudskog rješavanja maloljetničkih krivičnih predmeta, odnosno primjenu alternativnih (diverzionih) mjera u formi, primjera radi, posebnih obaveza određenih od strane državnog odvjetnika na temelju uvjetovane svrhovitosti u Hrvatskoj, odgojnih preporuka u Bosni i Hercegovini, te vaspitnih naloga u Srbiji i Crnoj Gori. Također, svi regionalni zakoni predviđaju da, premda se granica nastupanja krivično-pravnog maloljetstva $i$ odgovornosti veže za uzrast od 14 godina, starosna granica od kada se maloljetnim učiniteljima može izricati kazna maloljetničkog zatvora (granica kažnjivosti) je još veća i vezana je za uzrast od 16 godina.

Iako pojedini autori ${ }^{56}$ iznose argumente a propos uvođenja dviju minimalnih

54 Škulić, Maloletničko krivično pravo, 82.

55 Frieder Dunkel, Ineke Pruin, „Young Adult Offenders in Juvenile and Criminal Justice Systems in Europe" u: Young Adult Offenders: Lost in Transition? eds. Friedrich Losel, Anthony Bottoms, David Farringhton (New York: Routledge, 2012.): 33-34.

56 Marta Dragičević Prtenjača, Reana Bezić, „Perspektiva uvođenja doktrine doli incapax u hrvatsko maloljetničko kazneno pravo", Macedonian Journal for Criminal Law \& Criminology, (2018.): 30 . 
starosnih granica nastupanja krivične odgovornosti na temelju doli (in)capax doktrine, regionalna zakonodavstva de lege lata poznaju isključivo jednu granicu nastupanja krivično-pravnog maloljetstva, a kakvo rješenje i praksu ohrabruje i Komitet UN-a za prava djeteta.

Na kraju, međunarodni je standard da se krivično-pravno maloljetstvo završava sa navršenih 18 godina i impregniran je i u zakonodavstva država iz regiona. Ipak, značaj date starosne granice u legislativi država iz regiona, shodno preporukama međunarodnih dokumenata, relativiziran je mogućnošću primjene maloljetničkog krivičnog prava i na mlađe punoljetne osobe. S druge strane, za razliku od nekih uporednih zakonodavstava koja, suprotno međunarodnim standardima, otvaraju perspektive za upućivanje (transfer) maloljetnih učinitelja k sudovima opće nadležnosti, regionalni zakoni ne predviđaju takva zakonska rješenja.

Imajući u vidu prethodno navedeno može se zaključiti kako su sva relevantna pitanja, vezana za starosne granice krivično-pravnog maloljetstva i krivične odgovornosti maloljetnika, u legislativama država iz regiona uređena u skladu s međunarodnim standardima iz oblasti postupanja s maloljetnicima u sukobu sa zakonom.

\section{LITERATURA}

1. Arthur, Raymond. Young Offenders and the Law: How the Law Responds to Youth Offending. Abington: Routledge, 2010.

2. Carić, Ante. Mlađe osobe u kaznenom pravu (počinitelji $i$ žrtve). Zagreb: Pravni fakultet u Zagrebu, 2002.

3. Cherry, Andrew L., Valentina Baltag, Mary E. Dillon (eds.), International Handbook on Adolescent Health and Development: The Public Health Response. Cham: Springer International, 2017.

4. Childhood and Adolescence in Society: Selections from CQ Researcher. London: SAGE Publications, 2012.,

5. Cipriani, Don. Children's Rights and the Minimum Age of Criminal Responsibility: A Global Perspective. Farnham: Ashgate, 2016.

6. Decker, Scott H., Nerea Marteache. (eds.). International Handbook of Juvenile Justice. $2^{\text {nd }}$ ed. Vienna: Springer, 2017.

7. Dine, Janet, James Gobert, Wiliam Wilson. Cases and Materials on Criminal Law. Oxford: Oxford University Press, 2010.

8. Dragičević Prtenjača, Marta, Reana Bezić. „Perspektiva uvođenja doktrine doli incapax u hrvatsko maloljetničko kazneno pravo“, Macedonian Journal for Criminal Law \& Criminology 25, 1 (2018.): 1-37.

9. Dunkel, Frieder, Joanna Grzywa, Philip Horsfield, Ineke Pruin (eds). Juvenile Justice Systems in Europe: Current Situation and Reform Developments. Mönchengladbach: Forum Verlag Godesberg, 2010.

10. Filipčić, Katja. „Protislovja v razvoju koncepta odgovornosti mladoletnih prestupnikovov“. Zbornik znanstvenih rasprav 65, (2005.): 129-151.

11. Gurda, Vedad. „Osnovna obilježja zakonske i sudske politike primjene kazne maloljetničkog zatvora u Bosni i Hercegovini u uporednom krivičnom pravu i praksi““. Zbornik Pravnog fakulteta Sveučilišta u Rijeci 36, 2 (2015.): 787-812.

12. Hazel, Neal. Cros-National Comparison of Youth Justice. London: Youth Justice Board (YJB), 2008. 
13. Jašović, Žarko. Kriminologija maloletničke delinkvencije. Beograd: Institut za kriminološka i sociološka istraživanja, 2000.

14. Junger-Tas, Josine, Frieder Dunkel (eds.). Reforming Juvenile Justice, DordrechtHeilderberg-London-New York: Springer, 2009.

15. Junger-Tas, Josine, Scott H. Decker (eds.). International Handbook of Juvenile Justice, Cham: Springer, Dordrecht, 2006.

16. Losel, Friedrich, Anthony Bottoms, David P. Farringhton (eds.). Young Adult Offenders: Lost in Transition? London-New York: Routledge, 2012.

17. Maxwell, Gabrielle, Jeremy Robertson, Tracy Anderson. Police Youth Diversion - Final Report. Wellington: Crime and Justice Research Centre, Victoria University of Wellington, 2002.

18. Muzaffar Hussain, M. „Age of Criminal Responsibility and the Child Criminal Justice: Imperatives of Developmental Model of Juvenile Justice for India“. Fiat Iustitia, 2 (2017): 220-233.

19. Ottenhof, Reynald. „Criminal Responsibility of Minors in National and International Legal Order“. International Review of Penal Law 75, (2004): 51-74.

20. Puharić, Biljana, Ivana Radić. „Primjena načela svrhovitosti u postupanju prema maloljetnicima“. Hrvatski ljetopis za kazneno pravo i praksu 22, 2 (2015.): 635-670.

21. Radić, Ivana. „Hrvatski sustav maloljetničkih sankcija: trenutačno stanje i prijedlozi za promjenu“. Hrvatski ljetopis za kaznene znanosti i praksu 24, 1 (2017): 83-115.

22. Radulović, Ljiljana. „Maloletničko krivično pravo Engleske i Velsa - između ,etosa brige i zaštite“ i „etosa odgovornosti i kažnjavanja“. Anali Pravnog fakulteta u Beogradu 58, 1 (2010.): 195-211.

23. Rechea Alberola, Cristina, Ester Fernandez Molina. „Juvenile Justice in Spain: Past and Present“. Journal of Contemporary Criminal Justice 4 (2003): 42-57.

24. Rittossa, Dalida, Melita Božičević Grbić, „Zakon o sudovima za mladež - reformski zahvati i praktične dileme“. Hrvatski ljetopis za kazneno pravo i praksu 19, 2 (2012.): 615-667.

25. Stojanović, Zoran. Krivično pravo - opšti deo, 10. izd. Beograd: Dosije, 2015.

26. Škulić, Milan. Maloletničko krivično pravo. Beograd: Pravni fakultet Univerziteta u Beogradu, 2011.

27. Škulić, Milan. „Starosna granica sposobnosti za snošenje krivice u krivičnopravnom smislu“. Crimen 2 (2010.): 202-227.

28. Wiese, Katja Kristina. Juvenile Justice: A Comparison Between The Laws New Zealand and Germany, thesis (Christchurch, University of Canterbury, 2007.) www.http// ir.canterbury.ac.nz.

29. Zimring, Franklin E., Maximo Langer, David S. Tanenhaus. Juvenile Justice in Global Perspective. New York - London: New York University Press, 2015. 


\section{Vedad Gurda*}

Summary

\section{AGE LIMITS OF JUVENILE CRIMINAL RESPONSIBILITY IN COMPARATIVE LAW}

This paper presents a comparative legal overview of the juvenile age of criminal responsibility as an age framework in which young people enjoy a special (privileged) criminal status due to their immaturity. When it comes to the lower limit as minimum age of criminal responsibility, comparative legal solutions are different and they range from six or seven years in some countries, up to eighteen years in other. In most European countries, the age limit is set at the age of 14, which is the minimum age of criminal capacity proposed by UN Committee on the Rights of the Child. In comparative law the significance of the age limit is relativized by prescribing two or more such age limits (depending on the gravity of the crime or due to the application of the doli capax doctrine), as well as other legal solutions. On the other hand, in most countries, juvenile criminal responsibility lasts until the age of eighteen, although in some states in the United States and some other non-European countries it ends earlier. The importance of the age limit in some legislations is relativized by the possibilities of applying juvenile criminal law to young adults, but also through the possibility of referring minors to the criminal courts of general jurisdiction ("adult courts") even before the age of criminal majority. In the paper was analyzed international legal standards related to these issues, as well as legislative solutions in the countries of the region. In conclusion it was stated that the legal solutions contained in juvenile criminal legislation of the countries of the former SFR Yugoslavia are harmonized with international standards in this area.

Keywords: juvenile offenders; minimum age of criminal responsibility; young adults.

Zussamenfassung

\section{ALTERSGRENZEN DER STRAFRECHTLICHEN MINDERJÄHRIGKEIT: EIN RECHTSVERGLEICHENDER ÜBERBLICK}

Dieser Beitrag analysiert aus der rechtsvergleichenden Perspektive die

* Vedad Gurda, Ph.D., Associate Professor, Univesity of Tuzla, Faculty of Law; vedad.gurda@ untz.ba. 
Altersgrenzen der strafrechtlichen Minderjährigkeit, im Rahmen welcher jüngeren Personen aufgrund ihres Alters ein (sonder)strafrechtlicher Status zugeteilt wird. Die unterste Altersgrenze des Vorhandenseins der strafrechtlichen Verantwortung, erstreckt sich von sechs oder sieben Jahren bis zu achtzehn Jahren in einigen Staaten. In den meisten europäischen Staaten liegt diese Altersgrenze jedoch bei 14 Jahren, als der Grenze für die Fähigkeit gegen das Strafrecht zu verstoßen, wie vom UNAusschuss für Kinderrechte vorgeschlagen. Wie sich aus der Rechtsvergleichung ergibt, sei diese Altersgrenze in einigen Gesetzgebungen dadurch relativieret, dass zwei oder mehrere solche Grenzen vorgeschrieben sind (bedingt durch die jeweiligen Straftaten oder durch die Anwendung der Doktrin doli capax), sowie durch die Anwendung anderer Regelungen. Andererseits, in den meisten Staaten dauert die strafrechtliche Minderjährigkeit bis zum vollendeten achtzehnten Lebensjahr, obgleich in einigen US-Staaten und in Staaten außerhalb Europas diese Grenze niedriger liegt. Die Bedeutung der Altersgrenze wurde in einigen Gesetzgebungen durch die Möglichkeit das Minderjährigenstrafrecht auch in Bezug auf Heranwachsende anzuwenden, wie auch durch Verweisung (Transfer) der Minderjährigen auf die Strafgerichte der allgemeinen Zuständigkeit („Gerichte für Erwachsene“) noch während die Minderjährigkeit andauert. Es wurden daher internationale Standards, die sich auf diese Fragen beziehen, und Gesetzgebungsregelungen der Staaten aus der Region, analysiert. Wie schlussgefolgert, die Regelungen der ehemaligen Staaten Jugoslawiens, die minderjährige strafrechtliche Gesetzgebung umfassen, entsprechen den internationalen Standards.

Schlüsselwörter: minderjährige Straftäter; Altersgrenze der strafrechtlichen Verantwortung; Heranwachsende.

Riassunto

\section{LIMITI D'ETÀ NEL DIRITTO PENALE MINORILE NEL DIRITTO COMPARATO}

Nel lavoro è stata data una rassegna giuridica comparata dei limiti d'età nel diritto penale minorile, quale fascia d'età entro la quale le persone giovani, a causa della loro incapacità, godono di uno stato penale speciale (privilegiato). Quando si tratta del limite inferiore, come quel limite sopra il quale agisce il diritto penale minorile e la responsabilità, esso varia dai sei o sette anni in certi stati, sino ai diciotto anni. Nella maggior parte degli stati europei questo limite si collega all'età di 14 anni, la quale rappresenta l'età minima che propone il Comitato ONU sui Diritti dell'Infanzia per acquisire la capacità di violare la legge penale. Nel diritto comparato l'importanza di questo limite d'età è relativizzata dai due o più limiti d'età prescritti in certe legislazioni (secondo la gravità dei reati oppure a causa dell'applicazione della dottrina doli capax), come anche dall'applicazione di alcune soluzioni diverse. 
Dall'altra parte, nella maggior parte degli stati il diritto penale minorile è applicabile fino ai diciotto anni compiuti, anche se in alcuni stati degli USA ed in alcuni stati non europei esso finisce ancor prima. L'importanza di questo limite in alcune legislazioni è relativizzata dalla possibilità dell'applicazione del diritto penale minorile anche sulle persone adulte (giovani), ma pure dalla possibilità di mandare (trasferire) il minore al processo di fronte alle corti penali di competenza generale ("corti per gli adulti") anche prima che lo stato minorile sia terminato. Nel lavoro sono stati analizzati gli standard internazionali riguardanti queste questioni, ma anche le soluzioni legislative negli stati della regione dell'ex Jugoslavia. Infine è stato costatato che alcune soluzioni che contengono le legislazioni penali minorili negli stati del territorio dell'ex Jugoslavia sono in conformità con gli standard internazionali esistenti in quest'area.

Parole chiave: minori autori di reato; limite minimo per la responsabilità penale; giovani adulti. 